\title{
MICROSCULPTURE STUDY OF LATE PERMIAN AND EARLY TRIASSIC CONCHOSTRACANS FROM THE BABII KAMEN SECTION (WESTERN SIBERIA)
}

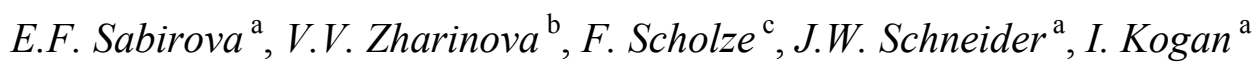 \\ ${ }^{a}$ Technical University Bergakademie, Freiberg, 09599 Germany \\ ${ }^{\mathrm{b}}$ Kazan Federal University, Kazan, 420008 Russia \\ ${ }^{\mathrm{c}}$ Hessisches Landesmuseum, Darmstadt, 64283 Germany
}

\begin{abstract}
The microsculpture of Permian and Triassic conchostracans from the Babii Kamen section (Western Siberia) was studied in order to determine the significance of microsculpture inthe taxonomy of conchostracan species. Five types of ornamentation have been identified in conchostracans from the Permian-Triassic reference section of Western Siberia (Babii Kamen section): pitted, nodular, reticulated, radial lirae, radial fringes. The results show that several microsculpture types are common for the genus level of conchostracans. Transition from one type of ornamentation to another was noted in three species: ?Megasitum lopokolense Novojilov, 1970, "Cornia papillaria" Lutkevich, 1937, and "Concherisma tomensis" Novojilov, 1958. The observed changes in the shell microsculpture types can be considered as a taxonomic feature for these three species and should form the base for future taxonomical revisions.
\end{abstract}

Keywords: Conchostraca, microsculpture, Late Permian, Early Triassic

\section{Introduction}

Permian and Triassic conchostracans are widely distributed in continental successions all around the world: they occur on the East European Platform, in Eastern and Western Siberia, Europe, Africa, Asia, Arabia, India, Antarctica, Australia, North and South America. Their use in biostratigraphy has been in focus of many research initiatives [1-5].

Of special interest $[1,6-15]$ is the shell microsculpture of these small crustaceans - a strengthening skeletal formation of the thin valves with a certain type, or with several types, of ornamentation -, which is a possible diagnostic feature of conchostracan genera and species. The key role of shell microsculpture for conchostracan identification was first stressed by N.I. Novojilov, who described four types of shell ornamentation (fine cellular, large cellular, streaky ribbed, and radial ribbed) [1]. Nevertheless, according to P. Tasch [16], the shell microsculpture is not a sufficient criterion for identification of conchostracan species, because the same species can have different types of shell ornamentation. 
To accurately identify the type of ornamentation, one should carefully study the microsculpture on all parts of the shell: at the umbo, in the central part of the valve, as well as at the anterior, ventral, posterior, and dorsal margins. It is noteworthy that the microsculpture is smaller at the anterior and posterior margins, because the width of growth bands in these parts of the shell is smaller.

\section{Materials and Methods}

The Babii Kamen section is located in the Kuznetsk coal basin (Kemerovo region, Western Siberia) on the right bank of the Tom River, $45 \mathrm{~km}$ downstream from Novokuznetsk. The section is represented by Permian coal-bearing sediments covered by Triassic volcanogenic-terrigenous rocks.

The section is divided into the Tailugan and Maltsevo formations (Fm.). The Tailugan Fm. is determined as Permian, while the Maltsevo Fm. as Triassic. The Maltsevo Fm. consists of the Tarakanikha, Barsuchii, Kedrovii, and Ryaboi Kamen members (Mb.).

Fossil remains in the Babii Kamen section are represented by ostracods, conchostracans, insects, gastropods, bivalve mollusks, fish scales, and terrestrial plants.

Conchostracans were sampled from the Babii Kamen section (in the upper layers of the Tailugan Fm. and Tarakanikha Mb., Kedrovii Mb., and Ryaboi Kamen Mb. of the Maltsevo Fm.) during 2015-2018.

The microsculpture of conchostracan shells was examined under a VEGAITESCAN scanning electron microscope. The drawings of conchostracan valves were made using a Leica stereomicroscope equipped with a mirror tube.

The types of conchostracan microsculptural ornamentation from the Babii Kamen section were determined using the methodology of conchostracan identification proposed by F. Scholze and J.W. Schneider [12].

The material is stored at the Geological Museum of Kazan Federal University (nos. 39/BK15, 39/BK16, and 39/BK18).

The description distinguishes the following main types of shell microstructure in conchostracans [12]: smooth, pitted, nodular, reticulated, radial reticulated, radial lirae, radial fringes. A smooth microsculpture means the absence of any ornamentation. The pitted type of ornamentation is built up by circular dimples on the valves. Rounded tubercles on the valves characterize the nodular microsculpture. Polygonal dimples on the valves is a feature of reticulated ornamentation. Ornamentation with lines perpendicular to the growth lines is attributed to the radial reticulated type. The radial lirae microsculpture typically features lines on the growth bands. A branched linear ornamentation with lines perpendicular to the growth bands is characteristic for the radial fringes type.

\section{Results}

The sampled conchostracans are tentatively assigned to seven genera: Pseudestheria Raymond, 1946, Cornia Lutkevich, 1938, Megasitum Novojilov, 1970, Echinolimnadia Novojilov, 1965, Concherisma Novojilov et Varentsov, 1956, Euestheria Depéret and Mazeran, 1912, and Hemicycloleaia Raymond, 1946. 
Pseudestheria Raymond, 1946 is characterized by oval shells with unequal anterior and posterior heights. This genus belongs to the family Lioestheriidae Raymond, 1946. P. novacastrensis (Mitchell, 1927) occurs in the Tarakanikha Mb. and Kedrovii $\mathrm{Mb}$. of the Babii Kamen section [18]. The species has a pitted type of shell microsculpture (Fig. 1). Reticulated microsculpture is typical for the shells of P. exigua (Eichwald, 1860) from the Monastery Ravine section and P. cf. itiliana (Novojilov, 1950) from the Cheremushka Ravine section in Tatarstan.

Cornia Lutkevich, 1938 is characterized by a narrow spine on the larval valve. This genus belongs to the family Vertexiidae Kobayashi, 1954 [4, 17]. A specimen identified as "C. papillaria" Lutkevich, 1937 was found in the Kedrovii Mb. of the Maltsevo Fm. in the Babii Kamen section [18]. The shell microsculpture of this species varies in different areas: the transition from reticulated ornamentation to radial fringes is visible on the growth bands of the shell (Fig. 1).

A droplet-shaped structure on the larval valve is the main characteristic for Megasitum Novojilov, 1970. Specimens similar to two species of this genus M. lopokolense Novojilov, 1970 and M. harmonicum Novojilov, 1970 were found in the Kedrovii Mb. of the Maltsevo Fm. [18]. Shell microsculpture types differ for these two species. Three different types of ornamentation were observed on the shell of ?M. lopokolense: pitted microsculpture at the umbo; radial fringes and reticulated microsculptures on the middle and ventral parts of the valve (Fig. 2). The microsculpture of ?M. harmonicum is on the inner side of the valve. Almost all specimens have badly preserved ornamentation on the outer side of the valve. Pitted ornamentation was observed on the valves of this species (Fig. 2).

Echinolimnadia Novojilov, 1965 is characterized by rounded, truncated valves with several radial rows of spikes. The specimens sampled from the Kedrovii Mb. and Ryaboi Kamen Mb. of the Maltsevo Fm. resemble E. mattoxi Novojilov, 1965 [18]. Reticulated ornamentation of the shell is characteristic for this species [19].

Specimens similar to Concherisma tomensis Novojilov, 1958 were found in the Kedrovii Mb. of the Maltsevo Fm. [18]. The reticulated microsculpture runs to the radial lirae at the anterior-ventral margin on the valves of this species. Some specimens of "C. tomensis" had pitted ornamentations (Fig. 3).

The species Euestheria gutta (Lutkevich, 1938) was registered in the Kedrovii $\mathrm{Mb}$. and Ryaboi Kamen Mb. in the Babii Kamen section. This species is an indicator of the Lower Triassic [4, 18, 20] and has a fine pitted shell microsculpture (Fig. 3).

Hemicycloleaia Raymond, 1946 has three radial ribs on the valve. This genus is part of the family Leaiidae Raymond, 1946 [17]. "Hemicycloleaia" specimens were sampled in the Kedrovii Mb. of the Maltsevo Fm. Preliminarily, three types of ornamentation were observed on their valves: reticulated microsculpture at the umbo; radial reticulated microsculpture in the middle part of the valve; and nodular ornamentation near the ventral margin (Fig. 3). 


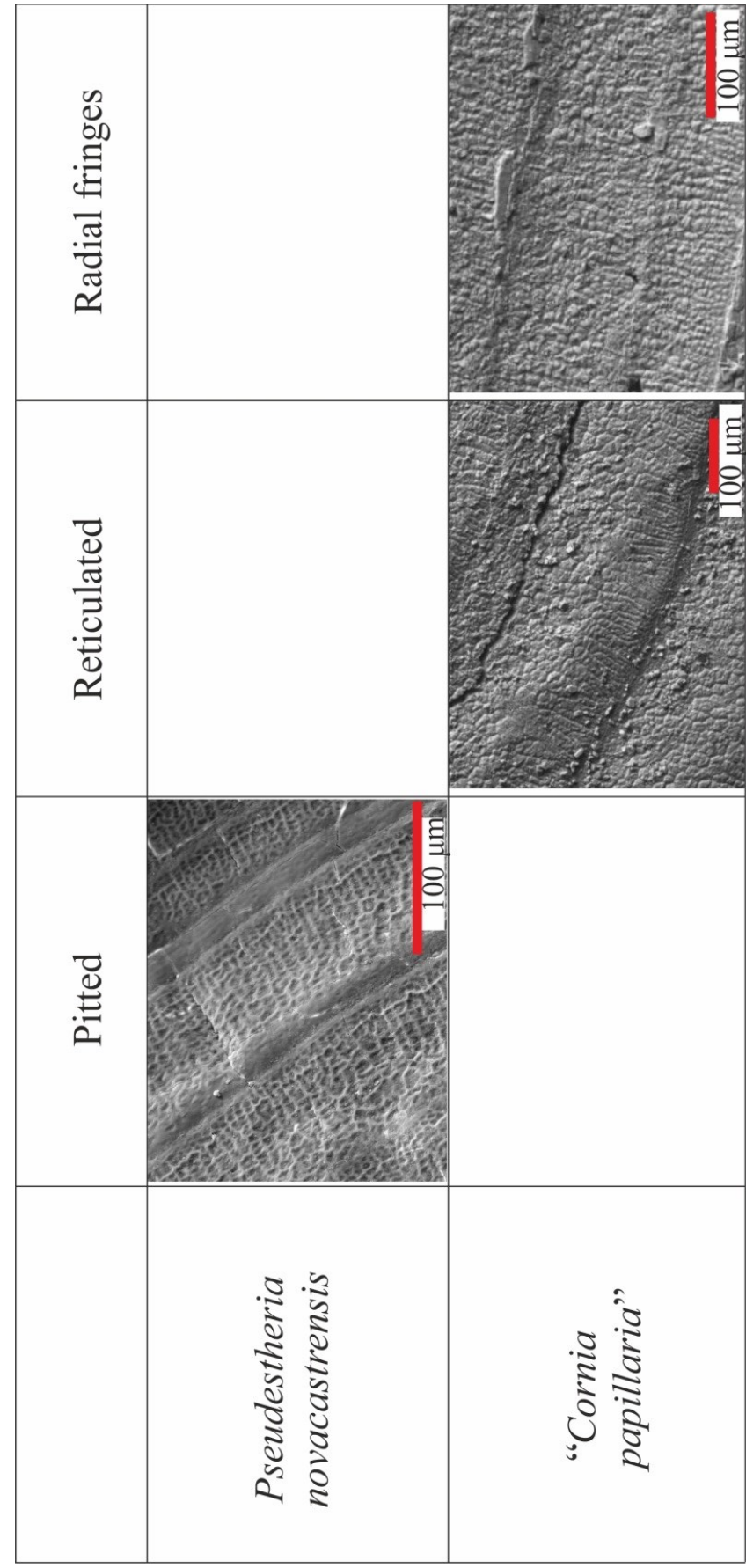

Fig. 1. Types of microsculpture on conchostracan shells from the Babii Kamen section. Pseudestheria novacastrensis - pitted type; "Cornia papillaria" - transition from reticulated type near the umbo to radial fringes ornamentation on the growth bands 


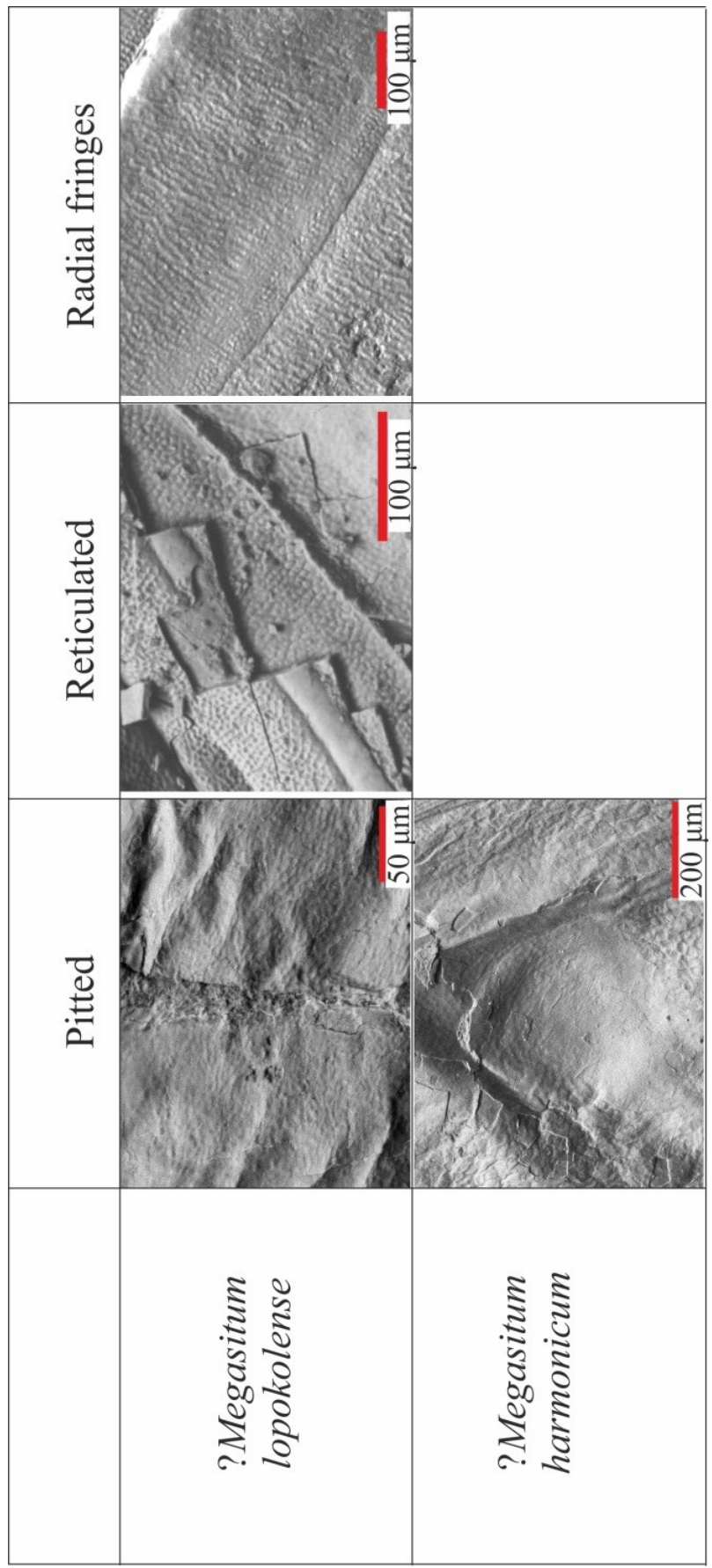

Fig. 2. Types of shell microsculpture on conchostracan shells from the Babii Kamen section. ?Megasitum lopokolense - pitted, reticulated, radial fringes types; ?Megasitum harmonicum pitted type. 


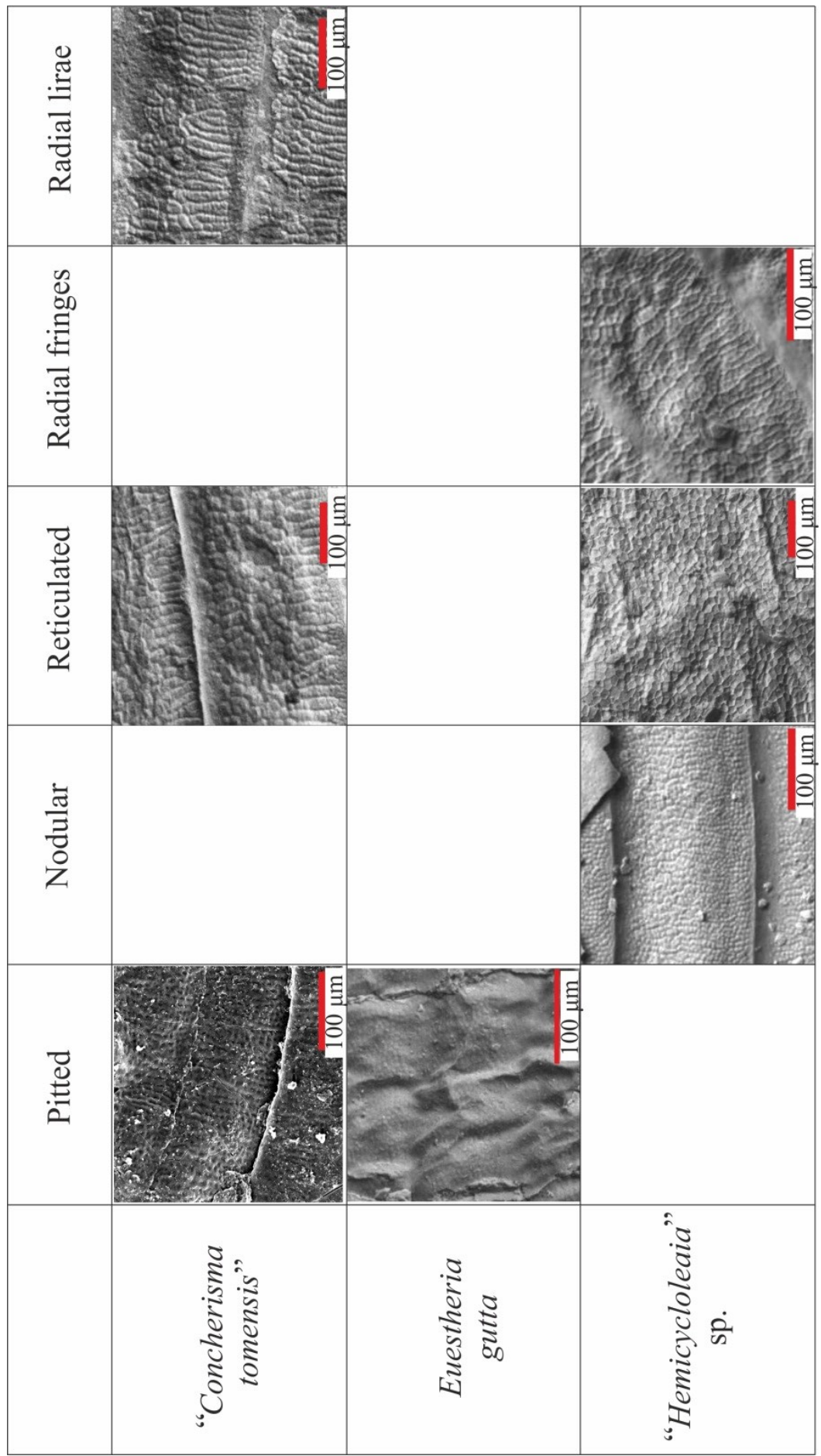

Fig. 3. Types of shell microsculpture on conchostracan shells from the Babii Kamen section. "Concherisma tomensis" - transition from reticulated to radial lirae type near the anteroventral margin. Some specimens have pitted ornamentation; Euestheria gutta - fine pitted type; "Hemicycloleaia" sp. - transition from reticulated type at the umbo to radial reticulated type in the middle part of the valve and nodular type near the ventral margin 


\section{Conclusions}

Shell microsculptures have been studied in several Late Permian and Early Triassic conchostracan taxa from Babii Kamen section in Western Siberia. Fossils tentatively attributed to the genera Cornia, Megasitum, and Concherisma ("Cornia papillaria", ?Megasitum lopokolense and "Concherisma tomensis") exhibit several types of ornamentation, suggesting that these forms might be characterized rather by a combination of microsculptures than by a single type. The taxonomic significance of such transitions from one ornamentation type to another, as well as their possible interpretation as indicative for changes of environmental conditions, remains to be explored in upcoming works.

Acknowledgments. We are grateful to E.A. Zhegallo, A.S. Bashkuev, D.S. Kopylov, A.V. Khramov, A.S. Felker, and O.D. Strelnikova from Paleontological Institute of the Russian Academy of Sciences for their invaluable help when sampling the material.

This study was supported by the Russian Science Foundation (project no. 19-1700178).

\section{References}

1. Novojilov N.I. Phyllopods of the Upper Jurassic and Cretaceous of Mongolia. Tr. Paleontol. Inst. Akad. Nauk SSSR, 1954, vol. 48, pp. 7-124. (In Russian)

2. Molin V.A., Novojilov N.I. Dvustvorchatye listonogie permi i triasa severa SSSR [Permian and Triassic Bivalved Phyllopods from the North of the USSR]. Nauka, 1965. $116 \mathrm{p}$. (In Russian)

3. Webb J.A. A reappraisal of the palaeoecology of conchostracans (Crustacea: Branchiopoda). N. J. Geol. Pal. Abh., 1979, vol. 158, no. 2, pp. 259-275.

4. Scholze F., Schneider J.W., Werneburg R. Conchostracans in continental deposits of the Zechstein-Buntsandstein transition in central Germany: Taxonomy and biostratigraphic implications for the position of the Permian-Triassic boundary within the Zechstein Group. Palaeogeogr., Palaeoclimatol., Palaeoecol., 2016, vol. 449, pp. 174-193. doi: 10.1016/j.palaeo.2016.02.021.

5. Schneider J.W., Scholze F. Late Pennsylvanian-Early Triassic conchostracan biostratigraphy: A preliminary approach. Geol. Soc., London, Spec. Publ., 2016, vol. 450, pp. 365386. doi: $10.1144 /$ SP 450.6 .

6. Shen Y.B. Review of the classification of the Family Afrograptidae (Crustacea: Conchostraca). Acta Palaeontol. Sin., 2003, vol. 42, no. 4, pp. 590-597.

7. Orlova E.F., Sadovnikov G.N. Microornamentation of Lioestheria, Mimoleaia, and Echinolimnadia (Conchostraca) from the terminal Permian of Siberia. Paleontol. J., 2006, vol. 40, no. 3, pp. 276-285. doi: 10.1134/S0031030106030075.

8. Orlova E.F., Sadovnikov G.N. Distribution and microsculpture of Limnadiidae, Falsiscidae, and Glyptoasmussiidae (Conchostraca) of the terminal Permian of Siberia. Paleontol. J., 2009, vol. 43, no. 6, pp. 631-639. doi: 10.1134/S0031030109060057.

9. Orlova E.F. Permian-Triassic conchostracan faunas from the North of Central Siberia Stratigr. Geol. Correl., 1999, vol. 7, no. 5, pp. 465-472. 
10. Li G., Chen P., Wang D., Batten D.J. The spinicaudatan Tylestheria and biostratigraphic significance for the age of dinosaur eggs in the Upper Cretaceous Majiacun Formation, Xixia Basin, Henan Province, China. Cretaceous Res., 2009, vol. 30, no. 2, pp. 477-482. doi: 10.1016/j.cretres.2008.09.002.

11. Tassi L.V., Monti M., Gallego O.F., Zavattieri A.M., Lara M.B. The first spinicaudatan (Crustacea: Diplostraca) from Permo-Triassic continental sequences of South America and its palaeoecological context. Alcheringa, 2013, vol. 37, no. 2, pp. 189-201. doi: 10.1080/03115518.2013.736793.

12. Scholze F., Schneider J.W. Improved methodology of 'conchostracan' (Crustacea: Branchiopoda) classification for biostratigraphy. Newsl. Stratigr., 2015, vol. 48, no. 3, pp. 287298. doi: $10.1127 / \operatorname{nos} / 2015 / 0065$.

13. Teng X., Xiao J.N., Zhang Y.W., Matsuoka A., Li G. Nestoria sikeshuensis (spinicaudatan), a new clam shrimp species from the Tugulu Group in Junggar Basin, northwestern China. Sci. Rep. Niigata Univ. (Geol.), 2016, vol. 31, pp. 75-81.

14. Hethke M., Fürsich F.T., Dchneider S., Iang B. Sex determination of the Early Cretaceous clam shrimp Eosestheria middendorfii (Yixian Formation, China). Lethaia, 2017, vol. 50, no. 1, pp. 105-121. doi: 10.1111/let.12180.

15. Liao H., Shen Y., Huang D. Serrated microstructures on carapaces of Eosestheria (Branchiopoda: Diplostraca) in the Early Cretaceous Jehol Biota and discussion on the taxonomic value of these structures. Cretaceous Res., 2019, vol. 95, pp. 310-317. doi: 10.1016/j.cretres.2018.11.023.

16. Tasch P. Branchiopoda, order Conchostraca. In: Moore R.C. (Ed.) Treatise on Invertebrate Paleontology; R, Arthropoda. Vol. 4. 1969, pp. 141-191.

17. Novojilov N.I. Subclass Gnathostraca. Suborder Conchostraca. In: Osnovy paleontologii (Chlenistonogie, trilobitoobraznye i rakoobraznye) [Fundamentals of Paleontology (Arthropods: Trilobites and Crustaceans)]. Moscow, Nauka, 1960, pp. 220-253. (In Russian)

18. Zharinova V.V. New data on the Late Permian and Early Triassic conchostracans from the Kuznetsk coal basin (Babii Kamen section). Mater. LXV sessii paleontologicheskogo obshchestva [Proc. LXV Sess., Paleontol. Soc.]. St. Petersburg, VSEGEI, 2019, pp. 53-55. (In Russian)

19. Novojilov N.I. Vymershie limnadioidei [Extinct Limnadioidea]. Nauka, Moscow, 1970. 249 p. (In Russian)

20. Scholze F., Golubev V.K., Niedźwiedzki G., Sennikov A.G., Schneider J.W., Silantiev V.V. Early Triassic Conchostracans (Crustacea: Branchiopoda) from the terrestrial PermianTriassic boundary sections in the Moscow syncline. Palaeogeogr., Palaeoclimatol., Palaeoecol., 2015, vol. 429, pp. 22-40. doi: 10.1016/j.palaeo.2015.04.002.

Recieved

April 18, 2019

Sabirova Elvira Firdausovna, Master's Degree Student

Technical University Bergakademie Freiberg

Bernhard-von-Cotta-Strasse 2, Freiberg, 09599, Germany

E-mail:ElFSabirova@stud.kpfu.ru

Zharinova Veronika Vladimirovna, Assistant Lecturer of Department of Paleontology and Stratigraphy

Kazan Federal University

ul. Kremlyovskaya 18, Kazan, 420008 Russia

E-mail:vevzharinova@kpfu.ru 
Scholze Frank, Doctor of Science, Research Fellow

Hessisches Landesmuseum Darmstadt Friedenspl 1, Darmstadt, 64283 Germany

E-mail:frank.scholze@geo.tu-freiberg.de

Schneider Jörg Walter, Professor, Doctor of Science, Professor at the Department of Paleontology and Stratigraphy

Technical University Bergakademie Freiberg

Bernhard-von-Cotta-Strasse 2, Freiberg, 09599, Germany

E-mail: joerg.schneider@geo.tu-freiberg.de

Kogan Ilja, Doctor of Science, Research Fellow at the Department of Paleontology and Stratigraphy

Technical University Bergakademie Freiberg

Bernhard-von-Cotta-Strasse 2, Freiberg, 09599, Germany

E-mail: ilja.kogan@geo.tu-freiberg.de

\title{
Микроскульптурные исследования позднепермских и раннетриасовых конхострак из разреза Бабий Камень (Западная Сибирь)

\author{
Э.Ф. Сабирова ${ }^{1}$, В.В. Жаринова ${ }^{2}$, Ф. Шольце ${ }^{3}$, Й.В. Шнайдер $^{1}$, И. Коган ${ }^{1}$ \\ ${ }^{2}$ Казанский (Приволжский) федеральный университет, г. Казань, 420008, Россия \\ ${ }^{3}$ Гессенский музей, г. Дармштадт, 64283, Германия
} \\ ${ }^{1}$ Технический университет Фрайбергской горной академии, г. Фрайберг, 09599, Германия
}

\begin{abstract}
Аннотация
Изучена микроскульптура пермских и триасовых конхострак из разреза Бабий Камень (Западная Сибирь) с целью установления значимости данного признака при определении видовой принадлежности конхострак. Выявлено и описано пять типов микроскульптурного орнамента конхострак: ячеистая, бугорчатая, сотовидная, линейная, линейно-разветвленная. Результаты исследования показывают, что несколько типов микроскульптурного орнамента могут являться одной из характеристик для родов Cornia, Megasitum и Concherisma. Переход от одного типа орнамента к другому характерен для трех видов: ?Megasitum lopokolense Novojilov, 1970, “Cornia papillaria" Lutkevich, 1937 и "Concherisma tomensis" Novojilov, 1958. Изменения типов микроскульптурного орнамента можно считать таксономической особенностью этих трех видов.
\end{abstract}

Ключевые слова: конхостраки, микроскульптура, поздняя пермь, ранний триас

Поступила в редакцию 18.04.19

Сабирова Эльвира Фирдаусовна, магистрант

Технический университет Фрайбергской горной академии ул. Бернхард-фон-Котта, д. 2, г. Фрайберг, 09599, Германия

E-mail:ElFSabirova@stud.kpfu.ru

Жаринова Вероника Владимировна, ассистент кафедры палеонтологии и стратиграфии

Казанский (Приволжский) федеральный университет ул. Кремлевская, д. 18, г. Казань, 420008, Россия

E-mail:vevzharinova@kpfu.ru

Шольце Франк, доктор наук, научный сотрудник

Гессенский музей

ул. Фридесплац, д. 1, г. Дармштадт, 64283, Германия

E-mail: frank.scholze@geo.tu-freiberg.de 
Шнайдер Йорг Вальтер, профессор, доктор наук, профессор кафедры палеонтологии и стратиграфии

Технический университет Фрайбергской горной академии

ул. Бернхард-фон-Котта, д. 2, г. Фрайберг, 09599, Германия

E-mail: joerg.schneider@geo.tu-freiberg.de

Коган Илья, доктор наук, научный сотрудник кафедры палеонтологии и стратиграфии

Технический университет Фрайбергской горной академии

ул. Бернхард-фон-Котта, д. 2, г. Фрайберг, 09599, Германия

E-mail: ilja.kogan@geo.tu-freiberg.de

For citation: Sabirova E.F., Zharinova V.V., Scholze F., Schneider J.W., Kogan I. Microsculpture study of Late Permian and Early Triassic conchostracans from the Babii Kamen section (Western Siberia). Uchenye Zapiski Kazanskogo Universiteta. Seriya Estestvennye Nauki, 2019, vol. 161, no. 2, pp. 348-357. doi: 10.26907/2542-064X.2019.2.348-357.

Для цитирования: Sabirova E.F., Zharinova V.V., Scholze F., Schneider J.W., Kogan I. Microsculpture study of Late Permian and Early Triassic conchostracans from the Babii Kamen section (Western Siberia) // Учен. зап. Казан. ун-та. Сер. Естеств. науки. - 2019. T. 161, кн. 2. - С. 348-357. - doi: 10.26907/2542-064X.2019.2.348-357. 